\title{
Life Cycle Analysis Methods on Environmental Impact Assessment (EIA) Procedures in the Perspective of Sustainable Development
}

\author{
Andreas Pramudianto ${ }^{1,}{ }^{*}$ \\ ${ }^{1}$ School of Environmental Science, University of Indonesia, Salemba Raya Street no. 4, Jakarta \\ 10430 Indonesia
}

\begin{abstract}
Basically each product or service has its own life cycle. Life Cycle Analysis Method can be used to assess the impact of an activity both production and service activities. Environmental Impact Assessment (EIA) or Analisis Mengenai Dampak Lingkungan (AMDAL) is one of the activities that must be fulfilled in order to obtain an environmental permit. EIA activities have a life cycle process that needs to be known and understood so that environmental permits can be obtained. Therefore this study aims to find out the use of the LCA method in EIA procedures. In addition, with the LCA method, EIA activities are expected to be well studied according to the function of this service. LCA can provide to reduce the least impact from environmental damage. This research will be useful for the development of environmental science, especially related to the study of environmental impacts, especially EIA. It is expected that the results of the study will provide a complete picture of the relevance of the LCA method with EIA and the benefits that can be taken. The results of this study will be an important recommendation for decision makers regarding the importance of EIA in development, especially sustainable development through the method used, namely LCA.
\end{abstract}

\section{Introduction}

Each product or service has its own life cycle. The life cycle will be different and have their own characteristics so it needs to be studied for further development of a science, especially in this case environmental science.

Use of the Life Cycle Analysis Method can assess an environmental impact of an activity and/or activities that produce products or services [1]. Every business and or activity that has an important impact must have an Environmental Impact Assessment (EIA) or Analisis Mengenai Dampak Lingkungan (AMDAL) [2]. This provision is regulated by Law Number 32 of 2009 concerning Environmental Protection and Management. The objective of achieving the EIA process is to achieve sustainable development. Sustainable development which consists of economic, social and environmental/ecological pillars is an effort for every business and /or activity in carrying out its business and activities so that it can last long in accordance with the initial planning.

\footnotetext{
* Corresponding author: uipram@gmail.com
} 
If it does not implement sustainable development, then the business and / or activity will not last long, because problems will arise which can be in the form of economic losses, social disturbances and environmental damage. As part of the concept of sustainable development, EIA equipment must be able to ensure its sustainability so that this device is also a requirement for obtaining environmental permits and businesses and/or activities. After obtaining an environmental permit and business license, the EIA device will continue to run through the implementation of the Environmental Monitoring Plan (RPL- Rencana Pemantauan Lingkungan) or often called implementation of the environmental permit. If an environmental permit is violated, the business license can be revoked. The main problem is that EIA has been a process that has been going on for a long time. In Indonesia, more than 25 years of EIA have been carried out, but rarely discussed as a sustainable development cycle, so it is necessary to conduct a cycle assessment process so that it can be known whether EIA can reduce the minimum environmental impact so that the concept of sustainable development can be achieved. Therefore, whether EIA is in accordance with the concept of sustainable development, especially the principle of sustainability will be known through the Life Cycle Analysis method.

\section{Research method}

The methodology used in this study uses the Life Cycle Analysis approach [3] [4]. The LCA that will be applied in this study is based on the ISO 14040 (2006) framework. In this LCA framework there are the following stages [5]:

a. Defining the limits and scope of LCA. In this stage, the boundary space and the scope of the LCA are used. The Life Cycle observed is starting from the business cycle and / or AMDAL activities that are included in the spatial plan to obtaining environmental permits and business permits.

b. Analysis Life Cycle Inventory (LCI). At this stage there will be potential for the influence of businesses and/or activities with the environment. Observations were made in the AMDAL activities related to the impact, analysis and operations.

c. Life Cycle Impact Assessment (LCIA) assessment. At this stage a total assessment is carried out from the results of the LCI analysis. In this case it will be seen how conformity is to the principle of sustainability.

d. Life cycle interpretation. At this stage a discussion of the results of the LCI and LCIA summary is discussed and discussed as a basis for conclusions, recommendations and improvement plans. In this study data collection, summary, and present the author's thoughts about several sources of literature from the topics discussed.

\section{Literature review}

Sustainable development has several important principles. But the point is the principle of sustainability becomes an important principle of sustainable development. The principle of sustainability associated with Life Cycle Analysis is intended to study how organizations can produce goods and services that are more useful, while reducing environmental impacts negative, and excessive consumption of natural resources [6]. Another meaning of sustainability is stated who propose sustainability as a result of society that allows future generations to at least have the same natural wealth as the current generation [7].

EIA is part of the development planning management tool so that the process is carried out in the planning stage. In this stage are achieved through various processes from the start of screening to obtaining environmental permits to business licenses. In addition to the planning stages, its must also be carried out as a stage of implementation and evaluation 
and mitigation through Environmental Management Plan (EMaP) or Rencana Pengelolaan Lingkungan (RKL) and Environmental Monitoring Plan (EMoP) or Rencana Pemantauan Lingkungan (RPL) documents. This cycle becomes important so that it can be identified with the suitability of the principle of sustainability so that the goals of sustainable development are achieved. To assess the sustainability of the EIA process, it can be based on the LCA model developed by ISO below.

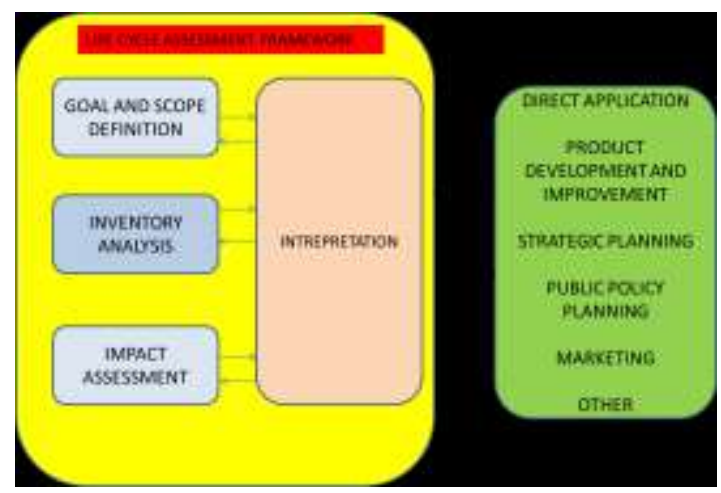

Fig. 1. Life Cycle Assessment framework.

\section{Result and discussion}

When determining the limits and scope of the LCA, it cannot be separated from the Environmental Impact Assessment (EIA) or AMDAL activities that are limited. In Indonesia, there are many regulations about Environmental Impact Assessment (EIA). In this figure, there are some regulations on EIA in year 2012-2018.

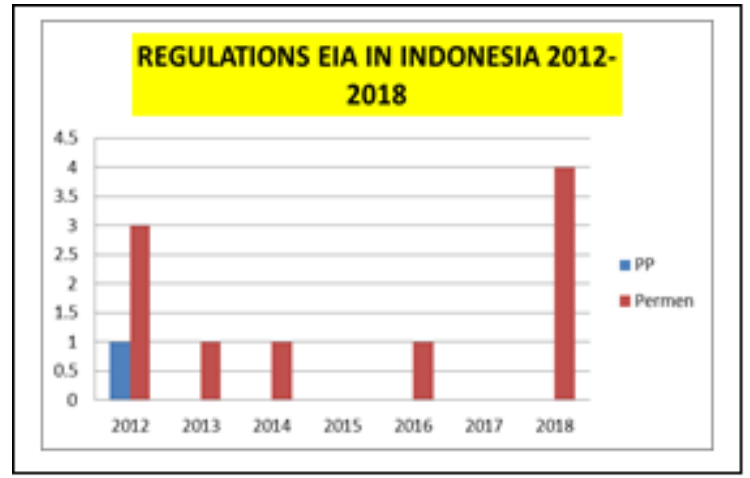

Fig. 2. Regulations EIA.

In the development process, a business and/or activity may not violate Spatial Planning or Tata Ruang has determined a business and/or activity entered into a particular area. This provision is regulated in Law Number 26 of 2007 concerning Spatial Planning and Government Regulation (GR) or Peraturan Pemerintah (PP) Number 26 of 2009 which is then amended into Government Regulation Number 13 of 2017. A business and/or activity is included in the EIA category or not, then a process known as the process screening. In this process a business and/or activity will fall into the category of having an important impact or not already known in advance. This provision is regulated in the Minister of Environment Regulation No. 05 of 2012 concerning the List of Compulsory EIA Criteria. 
After the EIA activities have been ascertained, the process of involvement and community participation. This process is regulated in Ministry of Environment Decree No. 17 of 2012. There are stages that must be carried out so that the EIA compilers are finally from the data of engagement, consultants can formulate the Terms of Reference for Environmental Impact Analysis or ToR EI Analysis or Analisis Dampak Lingkungan (ANDAL). After the ToR EI Analysis is completed, it will be submitted to the EIA Commission or Komisi AMDAL to be assessed by the EIA Technical Team. After obtaining approval from the EIA Technical Team, an Environmental Impact Analysis or (EI) Analysis and an Environmental Management Plan (EMaP) and Environmental Monitoring Plan (EMoP) or ANDAL, RKL and RPL are prepared. During this drafting process, field visits, laboratory sampling, dialogue, interviews, questionnaires and various other methods were needed to obtain information from environmental conditions. After the (EI) Analysis, EMaP and EMoP are completed, it is submitted to the EIA Commission to be assessed as well as a letter of application for an environmental permit. After the EIA Commission approves, an environmental permit is issued which forms the basis for the management of the business license. After a business license is obtained, the business and/or activity is built. After completion of construction, it is necessary to implement documents of EMaP and EMoP or environmental permits. All appointments in environmental permits must be implemented and adhered to so as to reduce the impact on the environment. If environmental impacts arise, mitigation measures must be taken. This all activities is goal and scope definition. (See Fig.1)

During the Life Cycle Inventory Analysis, each EIA activity must have valid and reliable data. The data can be in the form of input-output process data during the EIA process. The process of input or input from the community becomes very important to know the position and role of this business and / or activity in the future. In addition, data must also consider the historical or background, why the data needs to be taken. As an example of data regarding environmental conditions that must show clear and definite data. Data before businesses and or activities exist, it is important to be able to compare if they are already operating. This data will be related to all activities in the process of EIA commencing until obtaining an environmental permit and business license. If the data is obtained correctly and correctly, then the results of the EIA can help to show predictions in the future. Thus, this data will also affect the implementation of environmental permits, if this activity is already operational. (See Fig.1)

At the time of the Life Cycle Impact Assessment (LCIA), it is necessary to group and assess the impact on the environment. Data obtained from various EIA processes that have been carried out through Analysis Life Cycle Inventory (LCI). Based on the provisions of ISO 14040, it is carried out in the selection, classification and characterization stages. At the selection stage, a choice of impact categories is carried out. For example in the process of involving community participation there are people who disagree about the existence of a business and / or activity [8]. The impact will cause anxiety to the community. Then the LCA will assess the consequences of public anxiety about the surrounding environment. In classification, the LCI is taken only in one category of impact, for example an increase in dust will affect human health. To characterize the impact, use a science base. Data included in the LCA must be based on science. For normalization, a different barrier between impacts is needed. Likewise, grouping can be done according to the impact group. After that weighting is carried out, each must be given a certain weight. After everything is done, the results and evaluation must address the accuracy [9] that can be accounted for .

The next stage is interpretation. (See Fig.1). This stage has consistency, completeness, contribution, disruption and sensitivity and uncertainty. In interpreting certain conclusions can be drawn. In this case each process if implemented properly starting from determining the definition and scope of the correct EIA process in particular with accurate data based on 
the LCA inventory assessment which is then known to have an impact through LCIA assessment, it can be interpreted that the correct EIA process will be in accordance with the sustainability principle so sustainable development is achieved. This is because the EIA will provide a guarantee of good environmental planning certainty and the implementation of a plan that has been determined so that it will reduce the environmental impact more severely or even reduce environmental impact to a minimum. So that the guarantee of the existence of EIA will provide the sustainability principle of a business and / or activity when compared with the absence of EIA. With EIA, sustainable development will be achieved.

\section{Conclusion}

Sustainable development is a concept of development today.EIA or AMDAL is part of the concept of sustainable development that puts the principle of sustainability.. Through the Life Cycle Analysis (LCA) method, it can be seen that the correct EIA will be in accordance with the principle of sustainability so that sustainable development principle can be achieved.

\section{References}

1. European Environment Agency, Life Cycle Assessment (LCA) - A guide to approaches, experiences and information sources, Issue Report No 6 (SustainAbility, UK, 1997)

2. P.S. Hadi, Aspek Sosial Dalam AMDAL: Sejarah, Teori dan Metode [Social Aspects in EIA: History, Theory and Methods] (UGM Press, Jogjakarta, 2001)

3. P. Castka, C.J. Corbett, Found. Trends ${ }^{\circledR}$ Technol. Inf. Oper. Manag. 7, 3-4, 161-379 (2015)

4. A.G. Woodside, Case Study Research: Theory, Methods and Practice (Emerald Group Publishing, Boston, 2010)

5. A. Harvey, J.T. Meijer, J. Ozer, H. Al-Qadi, I.L. Saboori, A. Kendall, Pavement LifeCycle Assessment Framework (2016)

6. T. Ekvall, G. Assefa, A. Björklund, O. Eriksson, G. Finnveden, Waste Manag. 27, 8, 989-996 (2007)

7. S.B. Tsai et al., Renew. Sustain. Energy Rev., 77, 1169-1178 (2017)

8. G.K. Foster, Vand. J. Transnat'l L. 51, 39 (2018)

9. A.B. Bisinella de Faria, M. Spérandio, A. Ahmadi, L. Tiruta-Barna, Water Res. 84, 99 $111(2015)$ 